\title{
The Effect of Self-Efficacy to Mathematical Anxiety on Junior High School Students of YDM Learning Guidance Course Makassar
}

\author{
Dian Novita Siswanti \& Novita Maulidya Djalal \\ Faculty of Psychology, Makassar State University \\ novitamaulidya@yahoo.com
}

\begin{abstract}
Mathematics is often considered as one of difficult subject at school. It causes many students feel anxious when facing this subject. One of the factors that can affect mathematical anxiety is students' belief on their own ability which is called self-efficacy. The purpose of this study is to determine the influence of self-efficacy to anxiety when they are encountered with Mathematics subject. The proposed hypothesis is that self-efficacy has significant effect to mathematical anxiety experienced by junior high school students in YDM Learning Guidance Course Makassar. The population of this study were 75 students of grade VII, VIII, and IX of YDM Learning Guidance Course, and 30 among them were purposively selected as the participants. Self-efficacy scale adapted from Bandura and anxiety scale adapted from Holmes were utilized as instruments to collect the data. The validity test result of self-efficacy and anxiety scales was above 0.30 (valid), while the result of reliability test yielded 0.90 on self-efficacy scale and 0.923 on anxiety scale. Furthermore, the data were statistically tested by using regression test. The result showed that the significance value $\mathrm{p}$ $=0.001(<0.05)$, which means that there was a significant effect of self-efficacy to mathematical anxiety of junior high school students in YDM Learning Guidance Makassar.
\end{abstract}

Keywords: Self-efficacy, mathematical anxiety, junior high school students.

\section{BACKGROUND}

Mathematics is a special subject for students in the process of teaching and learning at school. This is because mathematics is assumed as one of the difficult subjects that often makes the students are feeling stress (Ormrod, 2004). The data from Kemendiknas (2010) states that $21.3 \%$ students fail to reach passing grade of Mathematics subject at the National Examination.

The basic problem is the high level of students' mathematical anxiety. Hurlock (2000) argues anxiety is an uncomfortable mental condition with regard to threatening or imagined pain. Furthermore, Taylor (1953) defines anxiety as a person's subjective feelings as a reaction to inability of solving a problem. The feeling of tension, apprehension, or fear that interferes with math performance is called mathematical anxiety (Ashcraft, 2002). Mathematical anxiety is also defined as a state of uncomfortable feeling that arises when facing mathematical problems in relation to fear and anxiety (Khatoon and Mahmood, 2010).

Mathematical anxiety experienced by students concerns with negative views that develop in society. Generally, students consider Mathematics as a difficult subject to be studied. Cockroft (in Krismanto, 2007) states that students usually consider Mathematics as unpleasant lesson and difficult to be understood. The stigma leads to feeling of anxiety to Mathematics which is called as mathematical anxiety.

Khatoon and Mahmood (2010) revealed that mathematical anxiety occurs almost at all levels of education, elementary level, primary and secondary level, and university level. The increase level of mathematical anxiety goes hand in hand with the higher level of education (Jackson and Leffingwell, 1999 \& Herman, 2005).

Based on the results of primary interviews conducted by the researchers to 5 (five) junior high school students in basic Mathematics learning of YDM Makassar in July 2017, it has revealed that students who have problem in Mathematics subjects tend to experience difficulty since entering the higher level of education. In other words, the complexity of Mathematics depends on students' point of view. They are often feeling doubt when completing mathematics tasks and exercises. As the result, students are afraid and anxious when they are learning in the class and having Math examination. Some students state that Mathematics is one of the most difficult subjects in order to obtain high scores. Hunsley (in Cassady, 2010) explains that poor achievement in terms of Mathematics is probably caused by negative stigma of the students about that Mathematics. Therefore, it can be said that mathematical anxiety causes students' difficulty to learn and apply the concept of Mathematics (Gleason, 2008).

Wigfield and Meece (in Ormrod, 2004) argue that students' belief on their ability to solve Mathematical problems is the influential factor contributing to anxiety. The cognitive process of belief of people ability to perform actions or certain tasks in order to achieve particular objectives is called self-efficacy (Bandura, 1997).

In everyday life, self-efficacy can lead a person to determine his expectations and help in solving problems in order to achieve his goals. Some studies showed that self-efficacy is able to 
predict a person's performance (Myers, 2002). When problems arise, strong sense of selfefficacy encourages a person to stay relax and find solutions rather than contemplating his inadequacies. This is consistent with the results of research conducted by Pajares and Kranzler (1995) that self-efficacy has an influence on the performance of Mathematics as much as the influence of mental ability. Based on the results of this study, it is known that students who have higher level of self-efficacy perform good actions in Mathematical calculations and show greater persistence than students who have low level of self-efficacy (Collins, 1982).

Based on the above explanation, it can be concluded that self-efficacy gives significant effect to Mathematical anxiety of students. Therefore, the researchers are interested to examine the influence between self-efficacy and Mathematical anxiety with the title "The effect of self-efficacy to Mathematical anxiety on junior high school students in YDM Learning Guidance Course Makassar".

\section{THEORETICAL REVIEW}

\section{Mathematical Anxiety}

\section{a) Definition}

Nawangsari (2001) defines anxiety as an unpleasant condition experienced by a person, including feeling of fear, tension, and insecure. Taylor (1953) defines anxiety as a person's subjective feeling that psychologically disturb mental tension as a reaction to the inability of overcoming a problem. Mathematical anxiety is defined by Suinn and Edwards (in Campbell, 2005) as a feeling of tension, anxiety or fear that disrupt a person's Mathematics achievement.

Ashcraft (2002) defines mathematical anxiety as a feeling of tension, anxiety, or fear that interferes with a person's performance in Mathematics. Another definition given by Tobias (in Dwikurniawati, 2014) who states that Mathematical anxiety is a feeling of tension and anxiety that interfere the process of numbers calculation, solving Math problems, and decreasing confidence in everyday life. In addition, Richardson and Suinn (1972) argue that Mathematical anxiety involves tense and anxious feelings that affect in various ways when solving math problems in academic and real life.

b) Symptoms of Mathematical Anxiety

Dacey (2000) suggests that the symptoms of anxiety include:

1) Psychological symptoms, including anxiety, nervousness, tension, uncomfortable, and insecurity, fear, and shock.

2) Physical symptoms, including palpitations, elevated blood pressure, cold perspiration in the palms, skin responses to outside stimuli diminish, increased peristaltic movement, somatic or physical symptoms (muscle), somatic or physical symptoms (sensory), respiratory symptoms (breathing), gastrointestinal symptoms (digestion), and urogenital symptoms (urinary and genital).

3) Social symptom, which is behaviors that are shown by a person when experiencing anxiety that is manifested in attitude.

Brody (2003) gives description about some symptoms of Mathematical anxiety. The first is Panic. Students experience several difficulties and feel they are at the threshold of Math lessons. The second is Paranoia, in which students think that everyone knows the answer from a mathematical problem except himself. The third is Passive, in which students act as if they can do nothing to improve their performances and are not able to make any effort for it. The last is Less confident, in which the students do not believe in their abilities. The students rely more on memorizing the formula than understanding the mathematical concepts.

c) Aspects

Nevid, Rathus, and Greene (2003) state there are 3 characteristics of anxiety, namely physical symptoms, cognitive symptoms, and behavioral symptoms. Physical symptoms include anxiety, nervousness, arms or limbs vibrating, sweating, sweaty palms, dizziness or fainting, dry mouth or throat, difficult to speak, difficult to breath, shortness of breath, rapid heartbeat, vibrating sound, feeling cold, and other physical disturbances. Cognitive symptoms are such as worry, fear, confusion, difficult to concentrate, feeling threatened, and unconfident. Meanwhile, the behavioral symptoms include avoidance behavior, inherent behavior, and shaken behavior.

d) Causal Factors

Wigfield and Meece (in Ormrod, 2004) explain two factors that affect mathematical anxiety; a) self-efficacy that is individual belief that he or she lacks of ability to solve math problems, and b) a person has a negative emotional reaction to mathematical problems, so he is afraid and did not like mathematics constantly.

Ellis (in Alsa, 1984) states that mathematical anxiety is caused by different level of intelligence of a person. This is in line with the opinion of Zeidner (1998) which said that mathematical anxiety causes individuals less interested in Math lessons. The lack of interest of the students in Mathematics according to Zeidner (1998) is caused by their intelligence. The higher the intelligence of a person is, the better his ability in Mathematics would be. Similarly, students who have lower intelligence will be less interested and less evaluative in Mathematics. Another study mentions that students who get low achievement in Mathematics are because they are less confidence to their ability (Scarpello, 2007). 
Wicaksono and Saufi (2013) point out some things that cause the child's fear of Mathematics, including:

1) Mathematics as a subject taught in schools is a specific branch of science that includes facts, processes, principles, and concepts. All Mathematics material requires a process of mathematical thinking, logical reasoning, and is considered relatively difficult because it requires consistency during the process.

2) Public perception that said Mathematics is difficult arouse students' negative thoughts about Mathematics.

3) Monotone activities in the class in which teacher center is very dominant.

4) Compulsion to get good scores by parents and teachers causes the students will only focus on result-oriented rather than the learning process.

\section{Self-Efficacy}

\section{a) Definition}

Bandura (1997) defines self-efficacy as the result of a person's cognitive process in the form of decision, belief, or expectation in performing particular action to reach the target goal. Baron and Byrne (1991) define self-efficacy as a person's evaluation of the ability to perform a task and overcome the challenges.

b) Aspects

Bandura (1997) states that self-efficacy consists of three dimensions, namely:

1) Dimension of level.

The dimension of level relates to the difficulty of a task, in which a person will able to complete that task according to the level and ability. This dimension has an impact on the choice of behavior, whether a person will try a task that he or she can do or avoid behavior that is beyond their capability.

2) Dimensions of strength

The dimension of strength relates to a person's level of confidence toward the ability. A weak belief to ability is closely related with bad experiences. Conversely, strong belief drives a person to stay in action although lack of support.

3) Dimensions of generalization

The dimension of generalization is concerned with the extent of the field of behaviour in which a person feels confident in his ability, even though limited exposure to particular activity and situation.

c) Self-Efficacy Source

Bandura (1997) argued that self-efficacy can be developed and studied from 4 major sources of information.

1) Mastery experience or performance accomplishments

A person who has successful experience will strengthen the level of a person's self-efficacy. In opposite, failure can decrease a person's selfefficacy. However, when a person experiences a failure and then succeeds through it, then that person will be able to shape his own efficacy by learning from the failure.

2) Vicarious Experience

Doing an observation on a successful person who is considered to have the same ability can improve self-efficacy, and vice versa, the failure experienced by a person who is considered to have the same ability can decrease the selfefficacy.

3) Verbal Persuasion

In verbal persuasion, people are directed by advice and guidance to enhance their beliefs about the capabilities they possess in order to achieve the desired goals. A person who is verbally convinced will tend to try harder to achieve a success.

4) Emotional-physiological state

Physical tension and sweating in a stressful situation are seen as a sign of incompetence because it can determine a person's performance.

\section{METHODOLOGY}

\section{Research Variable}

The variables in this research are Mathematical anxiety as dependent variable and self-efficacy as independent variable.

\section{Definition of Operational Variable}

a) Mathematical anxiety is a condition of students which is characterized by the feeling of anxiety, tension, and other physiological symptoms as seen from psychological, cognitive, motoric, and somatic aspects.

b) Self-efficacy in Mathematics is students' belief in their ability to complete mathematical tasks and activities. It is determined dimensions and strength based on Bandura's theory (1986).

\section{Research Instruments}

The purpose of this research is investigating the effect of self-efficacy on mathematical anxiety in grade IX students of Junior High School in YDM Learning Guidance Course. To be able to take the conclusion after the researchers collect the data, parametric technique by using SPSS with regression analysis technique was employed. The data were taken by using instruments of selfefficacy scale and mathematical anxiety adapted from Nursilawati (2010). The instruments were tested in terms of the validity and reliability before they were used. In this study, the validity and 
reliability tests are based on the results of previous experimental studies.

a) Validity test

A valid instrument means that the measuring instrument used to get the data is valid (Sugiyono, 2012). The researchers did not conduct instruments try out since the instruments have been tried out in the previous research and the result was used in this study. The self-efficacy scale yielded alpha value 0.933 with 49 statements items, and mathematical anxiety scale reached 0.923 of alpha 38 statement items.

b) Reliability test

Reliable instrument is when it is used to measure the same object multiple times will produce the same result (Sugiyono, 2012). The measurement of reliability is conducted by using statistical test Cronbach alpha $>0.60$ (Cronbach, 1991). The test results are based on the results of previous research try-out. Based on the results of the reliability test, self-efficacy scale yielded 0.90 of reliability test result, and mathematical anxiety scale resulted 0.923 . It means that both instruments yield high degree of reliability.

\section{Population and Sample Research}

a) Population

Populations are the generalization regions consisting of objects or subjects having certain qualities and characteristics defined by the researchers to be studied (Sugiyono, 2014). In this study, the populations are 75 students of grade VII, VIII, and IX Junior High School in YDM Learning Guidance Course.

b) Samples

The samples are part of the number and characteristics of the existing population (Sugiyono, 2014). In this research, the samples are 30 students of grade VII, VIII, and IX Junior High School in YDM Learning Guidance School who are willing to follow the whole process of research activities.

c) Data Analysis

The analysis used in this research is analytical analysis aimed at making decision (Suryabrata, 2003). The data were statistically analyzed by using SPSS with simple regression analysis.

d) Research Procedures

For the purpose of on target activity, the execution of research process is done by certain method. The method used in this activity is quantitative research method. Specifically, the research stages have been done as follows.

1.) Research Preparation. The preparation stage includes primary data collection using literature and prior research, creating a proposal, making appointment, and preparing the instruments.

2.) Research Implementation. The implementation stage of the research includes building rapport and spreading the scale of activities to students.
3.) Reporting. Stage compilation report consists of data input obtained from the subjects, data analysis, and compiling activity reports.

4.) Stage of reporting preparation. At this stage, the researchers tried to compile the research report that has been implemented and analyzed.

\section{RESULT}

The research process has been conducted smoothly in line with the planning even though there were some challenges that should be solved by the researchers. 30 subjects were involved in research activity, and actively asked when they do not understand the statements written on the psychological scale. According to the participants, this activity is useful for them because they know that they are experiencing mathematical anxiety. The process of filling selfefficacy and mathematical anxiety scales spent 3 days. The details of the results are as follows.

\section{Test Assumptions}

The number of subjects in this activity were 30 students. Shapiro Wilk was used to test the normality in which if the significance value $\mathrm{p}$ > 0.05 , then the data is normally distributed. Based on normality table, it is known that significance value in self-efficacy was $p=0.250(p>0.05)$ and significance value on mathematical anxiety $\mathrm{p}=$ 0.273 ( $p>0.05$ ). Thus, it can be concluded that the data is normally distributed.

\section{Hypothesis Testing}

Table 1. Simple Regression Test

\begin{tabular}{|c|c|c|c|c|}
\hline \multicolumn{5}{|c|}{ Summary Model $^{\mathbf{b}}$} \\
\hline Model & & RSquare & $\begin{array}{l}\text { Adjusted } \\
\text { R Square }\end{array}$ & $\begin{array}{l}\text { Std. Error } \\
\text { of the } \\
\text { Estimate }\end{array}$ \\
\hline 1 & $0.523^{\mathrm{a}}$ & 00.463 & 237 & 5.957 \\
\hline
\end{tabular}

\section{Result}

Based on the above table, it is known that $\mathrm{R}$ value is 0.523 which can be interpreted that there is a strong relationship between self-efficacy and mathematical anxiety. Furthermore, the R Square value indicates $46.3 \%$ which is interpreted that self-efficacy has a significant influence of $46.3 \%$ to mathematical anxiety, while the $53.7 \%$ is derived from other factors.

\section{DISCUSSION}

Based on the results of regression analysis test, it is known that the significance value is $\mathrm{p}=0.004(\mathrm{p}<0.05)$ which means the data were significant and met the linearity criteria. The $\mathrm{R}$ Square value showed $46.3 \%$ which is interpreted that the self-efficacy has influence of $46.3 \%$ to mathematical anxiety. This is in line with the results of research conducted by Chemers (in Zacacova, 2005) which showed that self-efficacy 
affected anxiety by influencing a person's confidence level.

Bandura (2003) states that self-efficacy is as a person's belief to master the situation and produce positive outcomes. Students who have confidence believe that they can control the results of the efforts that have been made to understand the mathematics learning materials so that the level of anxiety will be decreased. According to Schunk (1995), self-efficacy affects students in choosing their activities. Students with low self-efficacy may avoid difficult lessons and many tasks, especially for challenging tasks, while high selfefficacy students have a great desire to do their tasks.

Low self-efficacy can cause anxiety through two stages. The first stage, mathematical anxiety in students can arise due to unfulfilled expectations. The Second is low social ability. Bandura (1994) states that people who has good self-efficacy will be able to perform social relations well, as the result, they are able to explore information on how to solve a problem or challenge. Students who experience mathematical anxiety tend to stay away from the lesson. However, students who have good self-efficacy will make efforts to solve problems encountered through social interaction. Thus, students who have high level of self-efficacy can perform actions such as learning together with his friends or trying to find a solution and reduce anxiety. Indi (2009) mentions that the high level of student self-efficacy is, the lower the level of anxiety would be, and vice versa.

\section{CONCLUSION}

Based on the research, it can be concluded that self-efficacy has influenced on mathematical anxiety of junior high school students in YDM Mathematics Learning Guidance Course in Makassar with $46.3 \%$ of contribution, while $53.7 \%$ comes from other factors.

\section{REFERENCES}

Alsa, A. 1984. Usia Mental, Jenis Kelamin, dan Prestasi Belajar Matematika. Jurnal Psikologi Pendidikan, $12,1,22-29$.

Ashcraft, M.H. 2002. "Math Anxiety: Personal, Educational, and Cognitive Consequences". Directions in Psychological Science. 11.

Bandura, A. 1997. Self-Efficacy: The Exercise of Control. New York: W. H. Freeman and Company.

Bandura, A. 1977. Self-Efficacy: Toward a Unifying Theory of Behavioral Change. Psychological Review, 84, 191-215.

Bandura, A. 1997. Self-efficacy: The Exercise of Control. New York: W. H. Freeman Company.

Bandura, A,.\&Locke, E. A. 2003. Negative Self-Efficacy and Goal Effects Revisited. Journal of Applied Psychology. Vol. 88, No.1, 87-99. [Online]. http://www.emory.edu/education/. Tanggal akses: 21 Juni 2005.
Baron, R.A. \& Byrne, D. 1991. Social Psychology Understanding Human Interaction. Boston: Allyn $\&$ Bacon.

Brody, J. 2003. Problem Posing/Solving \& Linear Algebra. International Journalin Mathematics Education, Science and Technology. Volume 27: 103-121.

Cassady, J.C. 2010. Anxiety in Schools: The Causes, Consequences, andSolustions for Acedemic Anxieties. New York: Peter Lang Press.

Dacey, J.S. 2000. Your Anxious Child: How Parents and Teachers can Relieve Anxiety in Children. San Fransisco: Jossey-Bass Publishers.

Drajat. 1995. Kesehatan Mental. Jakarta: Gunung Agung.

Dwikurniawati, Annisa.2014. Prengaruh Kecemasan dan Self Efficacy siswa terhadap kemampuan pemecahan Masalah.Skripsi.Tidak dipublikasikan.Surabaya: Universitas Negeri Surabaya.

Erdogan, A., Kesici, S., \& Sahin I. 2011. Prediction of High School Studentse Mathematics Anxiety by Their Achievement Motivation and Social Comparison. Elementary Education Online, 10 (2), 646-652.

Gleason, J. 2008. Relationship between Pre-service Elementary Teachers ${ }^{\text {ee }}$ Mathematics Anxiety and Content Knowledge for Teaching. Journal of Mathematics Science and Mathematics Education, 3 (1), 39- 47.

Haciomeroglu, G.2013. Mathematics Anxiety and Mathematics Beliefs: What Is the Relationship in Elementary Pre-service Teachers? IUMPST: The Journal, 5.

Herman, T. 2005. Mengajar dan Belajar Matematika dengan Pemahaman, (Online), (http://file.upi.edu/Direktori, diakses 18 Agustus 2017).

Hurlock.2000. Psikologi Perkembangan Jilid 1. Jakarta: PT Gramedia PustakaUtama.

Indi, A. D. A. 2009. Hubungan antara Self-Efficacy dengan Kecemasan Berbicara di Depan Umum Pada Mahasiswa Fakultas Psikologi Universitas Sumatera Utara. Skripsi USU.

Karimi A \& Venkatesan S. 2009. Mathematics Anxiety, Mathematics Performance and Academic Hardiness in High School Students. International Journal of Education and Science. 1 (1), 33-37.

Kementrian Pendidikan Nasional. 2010. Laporan Ujian Nasional (UN) UtamaSMA dan MA (Madrasah Aliyah). 2010. Jakarta: Kementrian PendidikanNasional.

Khatoon, T. \& Mahmood, S. 2010. Mathematics Anxiety Among Secondary School Students in India and its Relationship to Achievement in Mathematics. European Journal of Social Science, 16 (1), 75-86.

Ma, X. 2003. Effect of Early Acceleration of Students in Mathematics on Attitude toward Mathematics and Mathematics Anxiety. Teachers College Record, 105 (3), 438-464.

Malinsky, M., dkk.. 2006. Math Anxiety in Pre-Service Elementary School Teacher. Education, 127 (2), 274-279.

Meece, J.L., Wigfiled, A., \& Eccles J.S. 1990. Predictors of Math Anxiety and Its Influence on Young Adolescentse Course Enrollment Intentions and Performance in Mathematics. Journal of Educational Psychology, 82 (1), 60-70.

Nawangsari, N.A.F. 2001. Pengaruh Self-Efficacy dan Expectancy-Value terhadap Kecemasan Menghadapi Pelajaran Matematika. Jurnal 
Psikologi Pendidikan: Insan Media Psikologi, 3,2, 2001, 75-88.

Nevid, Jeffrey S., Rathus, Spencer A. \& Greene, Beverly. 2003. Psikologi Abnormal. Jakarta: Erlangga.

Ormrod, J.E. 2004. Human Learning (4th Edition). Ohio : Pearson.

Pajares, F \& Miller, M.D. 1994. Role of Self Efiicacy and Self-Concept Beliefs in Mathematical Problem Solving: A Path Analysis. Journal of Educational Psychology, 86(2), 193-203.

Pajares, F. \& Graham, L. 1999. Self-efficacy, motivation constructs, and mathematics performance of entering middle school students. Contemporary Educational Psychology, 24, 124-139.

Scarpello, G. 2007. Helping students get past math anxiety. Techniques: Con-necting Education and Careers. 82(6), 34-35.

Schunck, D.H. 1995. Self-Efficacy and Education and Instruction. In J.E. Maddux (Ed,.), Self-Efficacy, Adaptation, and Adjusment: Theory, Research, and Application (pp.281-303) New York: Plenum.

Sherman, B.F. \& Wither, D.P. 2003. Mathematics Anxiety and Mathematics Achievement. Mathematics Education Research Journal, 15 (2), 138-150.

Supratiknya, A. (1995). Mengenal Perilaku Abnormal. Yogyakarta: PenerbitGrasindo.

Tobias, S. 1993. Overcoming Math Anxiety. New York: WW Norton.

Wicaksono, A.B., \& Saufi,M.2013. Mengelola Kecemasan Siswa Dalam Pembelajaran Siswa. Proceeding ISBN : 97897916353 94.Yogyakarta: Jurusan MIPA UNY.

Zeidner, M. 1998. Test Anxiety: The State of The Art. New York: Kluwer. 